\title{
Socioeconomic profile and degree of satisfaction of patients attending Gastroenterology Outpatient Clinics of a University Institution*
}

Perfil socioeconômico e grau de satisfação de pacientes que são atendidos em clínicas externas de gastrenterologia de uma instituição universitária

Perfil socioeconómico y grado de satisfacción de pacientes atendidos en clínicas externas de gastroenterología de un centro universitario

How to cite this article:

Costa MA, Carvente CT, Santos VN, Ferraz MLCG, Toledo CF. Socioeconomic profile and degree of satisfaction of patients attending Gastroenterology Outpatient Clinics of a University Institution. Rev Esc Enferm USP. 2019;53:e03436. DOI: http://dx.doi.org/10.1590/S1980-220X2018006303436

(D) Magali Angelica da Costa ${ }^{1}$
(D) Claudia Teresa Carvente ${ }^{1}$
(D) Virgínia Nascimento dos Santos ${ }^{1}$
(D) Maria Lucia Cardoso Gomes
Ferraz ${ }^{1}$
(D) Carlos Fischer de Toledo ${ }^{1}$
* Study presented for the Gastroenterology
course, as part of the requirements necessary to
obtain the Master's degree in Gastroenterology,
Universidade Federal de São Paulo, 2017
${ }^{1}$ Universidade Federal de São
Paulo, São Paulo, SP, Brazil.

Paulo, São Paulo, SP Brazil.

\begin{abstract}
Objective: To evaluate the degree of satisfaction and the socioeconomic profile of patients attending Gastroenterology Outpatient Clinics at a University institution linked to the Brazilian Unified Health System. Method: A researcher-administered questionnaire was applied during a structured interview in outpatient clinics. Results: Two hundred and forty (240) patients were included in the study (mean age of 53 years, 55\% women). About $30 \%$ of the patients had incomplete elementary education, $25 \%$ had complete secondary education, and 53\% were active workers. Approximately $87 \%$ attending the outpatient clinics were from the B2, C1 and C2 socioeconomic classes with an estimated family income of USD $\$ 275.00$ to USD $\$ 825.00 /$ month. Ninety-two percent (92\%) of patients were satisfied with the care received; the items associated with a lower degree of satisfaction were facilities/comfort, cleanliness, and waiting time for consultation. No relationship was observed between socioeconomic profile and degree of satisfaction. Conclusion: Satisfaction surveys are important to identify opportunities for improving healthcare services, and it is incumbent upon managers, health professionals and even users to promote compliance with laws and decrees that seek to improve healthcare.
\end{abstract}

\section{DESCRIPTORS}

Patient Satisfaction; Socioeconomic Factors; Health Services; Unified Health System; Brazil. 


\section{INTRODUCTION}

The search for healthcare quality in the Brazilian health system started with the introduction of the Federal Constitution of Brazil in $1988^{(1)}$, which established the creation of the Unified Health System (SUS in Portuguese Sistema Único de Saúde). The SUS was regulated by Law No. 8.080 of September 19,1990(2), which changed the concept and trajectory of public health in Brazil.

Measuring healthcare quality is not an easy task, especially in the public sector. No standardization exists for the techniques and parameters to be evaluated, in addition to variations in values, customs and ideologies. The Federal Government established the first norms that regulated the quality standards for public health services with Decree No. 3.507 , dated June $13,2000^{(3)}$. After repeal of this decree and the implementation of the Citizen Services Charter ${ }^{(4)}$, the search for healthcare quality extended to all public, federal, state and municipal, administration bodies. The purpose of the Charter was to improve the relationship between the public administration and citizens in order to disseminate the services provided by public organizations, to strengthen the trust and credibility of the public administration, and to guarantee the right of citizens to receive services according to their needs ${ }^{(4)}$.

In order to promote and consolidate attitude changes in all healthcare practices, the Ministry of Health, through the Decree No. 675 of March 30, 2006 (5), instituted the Charter of Rights of Health System Users ${ }^{(6)}$, based on the six basic principles of citizenship: 1) Every citizen has the right to orderly and organized access to health systems; 2) Every citizen has the right to appropriate and effective treatment; 3) Every citizen has the right to humanized treatment free from any discrimination; 4) Every citizen has the right to care that respects his/her person, values and rights; 5) Every citizen also has responsibilities for their treatment to occur properly; 6) Every citizen is entitled to the commitment of healthcare managers so that the cited principles are met. Thus, citizens must know their rights as users of the health system and contribute to improving healthcare quality. The document also suggests managers, health professionals and civil organizations to promote respect for these rights.

Knowledge about the patient's perception of the care received has been a matter of concern for researchers and healthcare professionals and is used by both public and private services. Some authors ${ }^{(7-8)}$ consider this perception to be synonymous with satisfaction, and although different conceptual approaches to patient satisfaction exist, they agree that its definition is complex and subjective, and must start from the perspective of the patient. This definition should also take into consideration that people may differ in the judgment of their satisfaction because, in addition to beliefs and values, they have individual experiences of the care received.

Patient satisfaction has been used as a criterion for measuring healthcare service quality over the past decades. Thus, knowing the degree of patient satisfaction with the care received and the factors that affect this perception is important for the healthcare team since it will contribute to improving the provided care and treatment, and is the basis for the team to plan care and to provide quality service ${ }^{(9)}$.

Since the population attended at the outpatient clinics of an academic hospital is highly heterogeneous, the objective of this study was to characterize the perception of healthcare quality by evaluating the degree of satisfaction and the socioeconomic profile of patients attending Gastroenterology Outpatient Clinics of our university hospital.

\section{METHOD}

STUdY DESIGN

A clinical, prospective and descriptive study.

\section{SCENARIO}

Was conducted at the Outpatient Clinics of the Gastroenterology Division (Universidade Federal de São Paulo/UNIFESP - Hospital São Paulo) between February 10 and June 3, 2014.

\section{Data collection}

Data were collected at the outpatient clinic of each subspecialty over a period of 4 weeks.

Two hundred and forty patients (240) were interviewed, corresponding to approximately $20 \%$ of patients that attended each outpatient clinic during the established period. The outpatient clinics of the following subspecialties were evaluated: Stomach, Hepatitis I and II, Pancreas, Oncology, Digestive Motility, Cirrhosis, Schistosomiasis, and Intestine. These clinics were chosen because they concentrate the largest number of patients of the Clinical Gastroenterology Division of the hospital.

The patients were selected randomly and consecutively. The questionnaire was applied personally by structured interviews ${ }^{(10)}$. The interviewer read the questions and alternatives out loudly and the participants chose the most adequate alternatives without any interference from the interviewer.

The following categories were used to classify the degree of satisfaction with care: excellent, good, regular, fair, and poor. The care received at the outpatient clinics was evaluated by applying a structured questionnaire with 24 questions, which were elaborated according the Citizen Services Charter ${ }^{(4)}$. In order to classify the degree of patient satisfaction with the care received, some variables that directly influence the patient's opinion were analyzed such as appointment waiting time, the care received from healthcare professionals, the language used by healthcare professionals, the physical environment (comfort/welfare, and hygiene/ cleanliness), and waiting time for consultations.

The different parameters were analyzed by dividing the population into two categories according to socioeconomic profile (Ia: classes A and B; Ib: classes C, D and E) ${ }^{(4)}$ and satisfaction (IIa: excellent and good; IIb: regular, fair and poor). Satisfaction was also rated as present (yes) and absent (no). The socioeconomic profile of the participants was defined using the Economic Classification Criteria established by the Brazilian Association of Research Companies (ABEP) ${ }^{(11)}$. 


\section{DATA ANALYSIS AND PROCESSING}

ANOVA, chi-squared test and a test for equality of two proportions were used for data analysis and comparison. A 95\% confidence interval was defined, considering a significance level of $5 \%(\mathrm{p}<0.05)$.

\section{ETHICAL ASPECTS}

The patients who agreed to participate signed the free informed consent form approved by the Ethics Committee of HSP/UNIFESP (No. 458.252/2013), according to the norms of Resolution 466/2012, of the National Health Council. In the consent template, the signed patients answered questions about personal and family data, including name, gender, age, race, marital status, education level, occupation, and household income.

\section{RESULTS}

\section{General CHARACTERISTICS OF THE SAMPLE STUDIED}

The sample was characterized by a slight predominance of females $(55 \%)$ over males $(45 \%)$ and the mean age $( \pm$ SD) was $54 \pm 13$ years (Table 1 ). Among the 240 patients interviewed, 153 (64\%) defined themselves as white, 133 (55\%) were married, and 126 (53\%) were active workers, including $30 \%$ in the private sector and $20 \%$ self-employed.

Table 1 - General characteristics of the studied sample - São Paulo, SP, Feb/Jun, 2014.

\begin{tabular}{lcc}
\hline Age (years) & & \\
\hline Mean & 53.7 & \\
Range & $16-80$ & \\
Standard deviation & 13.2 & $\mathbf{n}$ \\
\hline Gender & $\%$ & 108 \\
Male & 45.0 & 132 \\
Female & 55.0 & \\
\hline Race & & 153 \\
White & 63.7 & 49 \\
Brown & 20.4 & 34 \\
Black & 14.2 & 4 \\
Yellow & 1.7 & \\
\hline Marital status & & 133 \\
Married & 55.4 & 59 \\
Single & 24.6 & 14 \\
Divorced & 5.8 & 13 \\
Separated & 5.4 & 21 \\
Widowed & 8.8 & 52 \\
\hline Occupation & 2.1 & \\
Private sector & 30.0 & \\
Public servant & 2.1 & \\
Self-employed & 19.6 & \\
Student & & \\
Retired/Pensioner & 20.4 & \\
\hline Others & & \\
\hline & & \\
\hline
\end{tabular}

Note: $(n=240)$.
With respect to education level, $30 \%$ of the patients had incomplete elementary school, $27 \%$ had completed high school, $11 \%$ had higher education, and only $6 \%$ were illiterate (Table 2).

According to the ABEP classification ${ }^{(11)}$, most patients (87\%) were found in $\mathrm{B} 2, \mathrm{C} 1$ and $\mathrm{C} 2$ socioeconomic classes, with an estimated household income of USD $\$ 275.00$ to USD $\$ 825.00 /$ month. There are classes A2 and B1 at the extremes, which accounted for only $6 \%$ of the studied sample, and classes D and E accounting for 8\% (Table 3).

Table 2 - Distribution of the patients according to education level - São Paulo, SP, Feb/Jun, 2014.

\begin{tabular}{lcc}
\hline Education level & $\mathbf{n}$ & $\%$ \\
\hline Illiterate & 14 & 5.8 \\
Incomplete elementary school & 72 & 30.0 \\
Complete elementary school & 38 & 15.8 \\
Incomplete high school & 13 & 5.4 \\
Complete high school & 64 & 26.7 \\
Incomplete higher education & 10 & 4.2 \\
Complete higher education & 26 & 10.8 \\
Post-graduation & 3 & 1.3 \\
\hline
\end{tabular}

Table 3 - Socioeconomic classification of the patients - São Paulo, SP, Feb/Jun, 2014.

\begin{tabular}{lcc}
\hline Socioeconomic class & $\mathbf{n}$ & $\%$ \\
\hline A1 & 0 & 0.0 \\
A2 & 3 & 1.3 \\
B1 & 11 & 4.6 \\
B2 & 58 & 24.2 \\
C1 & 87 & 36.3 \\
C2 & 63 & 26.3 \\
D & 16 & 6.7 \\
E & 2 & 0.8 \\
\hline A1: 42-46; A2: 35-41; B1: 29-34; B2: 23-28; C1: 18-22; C2: 14-17; \\
D: 8-13; E: 0-7. Economic classification criteria ${ }^{(11)}$.
\end{tabular}

Regarding origin, most patients were referred from public hospitals, including São Paulo Hospital (48\%), $25 \%$ were referred from health centers, and the remaining $27 \%$ were referred from other services or did not respond. Analysis of access to medical care showed that $80 \%$ of the patients had no health insurance, while the remaining 20\% attending the public health service had health insurance.

Only $7 \%$ of the patients reported their first outpatient attendance, while the remaining $93 \%$ had already been under follow-up at the outpatient clinics. The mean follow-up time at the clinics was longer than 6 years (78 months).

\section{Classification of the patients Regarding CARE RECEIVED}

With respect to appointment waiting time, $73 \%$ of the patients classified it as excellent and good. Most participants reported the care received by professionals upon admission by nurses and during medical and nutritional treatment to 
be excellent and good. More than $70 \%$ of the patients did not receive nutritional treatment (Table 4).

More than $90 \%$ of the patients reported to have been treated with attention, respect and courtesy by the receptionists, nursing staff, doctors, and nutritionists. About $94 \%$ of the participants stated that their doubts had been clarified by the physician, classifying the care as excellent and good. With respect to the language used during the medical or nutritional consultation, $98 \%$ of the patients understood the instructions and explanations received.

The overall quality of care was classified as excellent and good by $87 \%$ of the patients. When asked if their expectations were met and if they were satisfied, $92 \%$ of the patients answered yes.

Comfort/welfare and hygiene/cleanliness of the care facilities were classified as excellent and good by $59 \%$ and
$70 \%$ of the patients, respectively. However, the number of patients who classified these two items as regular, fair or poor was significant ( $41 \%$ and $30 \%$, respectively).

Although satisfied with the care received, $55 \%$ of the patients were unsatisfied with the waiting time for consultation. About $80 \%$ of the patients were attended within 4 hours, while the remaining $(20 \%)$ had to wait more than 4 hours for consultation (data not shown).

Regarding knowledge about which procedures should be adopted in the case of complaints or suggestions, more than $75 \%$ of the patients did not know how to proceed and were unaware of the ombudsman service.

Comparative analysis of the degree of satisfaction according to socioeconomic profile of the patients revealed no significant differences (Table 5).

Table 4 - Classification of the degree of satisfaction of patients according to the healthcare professional - São Paulo, SP, Feb/Jun, 2014.

\begin{tabular}{lccc}
\hline Professional & Excellent/Good (\%) & Regular/Fair/Poor (\%) & No attendance (\%) \\
\hline Receptionists & 87.9 & 12.1 & 0 \\
Nursing staff & 75.4 & 5 & 19.6 \\
Physicians & 95.5 & 4.5 & 0 \\
Nutritionists & 28.8 & 0 & 71.2 \\
\hline
\end{tabular}

Table 5 - Comparative analysis of the degree of patient satisfaction according to socioeconomic profile - São Paulo, SP, Feb/Jun, 2014.

\begin{tabular}{|c|c|c|c|c|c|c|c|c|}
\hline \multirow{3}{*}{ Satisfaction } & & \multicolumn{6}{|c|}{ Socioeconomic profile } & \multirow{3}{*}{ p } \\
\hline & & \multicolumn{2}{|c|}{ la } & \multicolumn{2}{|c|}{ Ib } & \multicolumn{2}{|c|}{ Total } & \\
\hline & & $\mathbf{n}$ & $\%$ & $\mathbf{n}$ & $\%$ & $\mathbf{n}$ & $\%$ & \\
\hline \multirow[t]{2}{*}{ Being satisfied } & Yes & 66 & 91.7 & 157 & 93.5 & 223 & 92.9 & \multirow{2}{*}{0.621} \\
\hline & No & 6 & 8.3 & 11 & 6.5 & 17 & 7.1 & \\
\hline \multirow[t]{2}{*}{ Degree of satisfaction } & Illa & 63 & 87.5 & 145 & 86.3 & 208 & 86.7 & \multirow{2}{*}{0.804} \\
\hline & Illb & 9 & 12.5 & 23 & 13.7 & 32 & 13.3 & \\
\hline
\end{tabular}

Chi-squared test. Ia (classes A and B); Ib (classes C, D and E); IIa (excellent and good); IIb (regular, fair and poor).

\section{DISCUSSION}

Few studies have evaluated the degree of satisfaction of patients attending specialized public outpatient services. The Gastroenterology Division of UNIFESP was the first service in the institution to conduct a study associating socioeconomic profile with the degree of patient satisfaction at their subspecialty clinics.

The first step to provide client satisfaction is a broad understanding of their needs in order to build effective and consistent working methods. The organization must transform these needs into requirements to achieve this goal. This will require dedication and resources to systematically collect and analyze the data and information in an attempt to understand client demands and perceptions ${ }^{(12-13)}$. Therefore, the present study aimed to obtain information about patients' perception of the care received in order to understand their needs and to establish measures to improve healthcare quality.

The patients attending the outpatient clinics of the Gastroenterology Division generally did not differ from those seen at other public health services, including other sectors of the São Paulo Hospital ${ }^{(14-16)}$. Most patients are treated within SUS and are referred from public hospitals and health centers. They are middle-aged and there is a slight predominance of females and patients with incomplete elementary school.

The predominant socioeconomic profile was class $\mathrm{C}$ (Table 3), and $20 \%$ of the evaluated sample had health insurance. Patients with private insurance sought a public health service in order to receive specialized care with physicians that are more qualified. Furthermore, the patients trust in the professionals, they have knowledge of the role of the University hospital as a referral center, and sometimes they need access to expensive medications such as those for autoimmune, viral hepatitis and intestinal inflammatory diseases, which are only delivered to the public through the public health system.

The main healthcare expectations of patients cited in different studies are attention, respect, sympathy and efficiency on the part of doctors and employees, an adequate physical structure, and a short waiting time ${ }^{(14,17-18)}$. The questionnaire implemented in the present study was elaborated to seek these points. The healthcare professionals (doctors and 
nutritionists) had an approval rate of about $100 \%$ in terms of instructions and explanations, using a concise and easy language during consultation, which satisfactorily contributed to treatment. Good adherence by the patient, including attendance to the service and rigorous compliance with the prescribed medical management, is fundamental for treatment success ${ }^{(19)}$. A study conducted at UNIFESP(20) also reported that $80 \%$ of the patients had their doubts about treatment fully clarified by the doctors.

We obtained an $87 \%$ rate of excellent and good satisfaction. However, the rate decreased to $59 \%$ for satisfaction with the physical structure of the facilities. A possible explanation for this lower rate are the large number of scheduled patients and the structure of the outpatient clinics that does not support the demand. The facilities are precarious and the number of patients increases steadily, since UNIFESP is a referral center for different areas in Gastroenterology.

The approval rate for hygiene and cleanliness of the health facilities was 70\%. As any public service in Brazil, the São Paulo Hospital has basic resources, which are not always sufficient. Both professionals and patients must use these resources consciously to avoid the waste and misuse of public funds.

The average waiting time for consultation was 3 to 4 hours. This was one issue of dissatisfaction, but a certain tolerance on the part of the patients was noticed, who feel rewarded by the attention and respect received throughout the care process. This dissatisfaction with waiting times has also been reported by other authors ${ }^{(21-22)}$.

Overall, we found a very positive evaluation by users, which was a somewhat unexpected finding. Such positive results obtained in the majority of studies are probably due to the low critical capacity of users since they have become accustomed and have learned to lower their expectations of health services ${ }^{(23)}$.

We also compared the degree of satisfaction according to the number of patients/number of attending physicians (data not shown) and found no significant difference. Analysis of the degree of satisfaction according to the presence of undergraduate medicine students during treatment revealed a slight tendency towards the patients being less satisfied (data not shown). This result differs from those already reported ${ }^{(15)}$, which compared the care provided exclusively by doctors and that provided by medical students accompanied by a preceptor. In that study, the pattern of excellent quality was significantly more frequent for treatment provided by medical students and preceptors at primary healthcare units. A possible explanation for the dissatisfaction found in our study is the inadequate physical space, large number of patients, and the consequently longer waiting time because of discussion of the cases with the preceptor.

We found no differences in the degree of satisfaction according to the socioeconomic profile category. Most patients were satisfied with the care received, regardless of their socioeconomic class.

An item about complaints, claims and suggestions was included in the questionnaire. More than $75 \%$ of the patients did not know where and how to make complaints. These data agree with the study in which $68 \%$ of the patients did not know which procedures should be adopted in these cases ${ }^{(22)}$. Most patients are unware of the ombudsman service, indicating that this information has to be more present and disseminated to users. Registering satisfaction or dissatisfaction of health service users at ombudsman offices is an important indicator for institutional and professional improvement ${ }^{(24)}$.

The lack of preparation on the part of healthcare users regarding technical evaluation and assessment of professional competence is well known, but attention, respect, courtesy, effective communication and punctuality are determinant variables for healthcare quality and satisfaction ${ }^{(25-26)}$. Another study ${ }^{(27)}$ highlighted the need of users to understand the use of health services as a right, demanding high-quality care and assuming a participatory role in the institutions and not as if they were receiving a favor, as is ensured in the Charter of Rights of Health System Users ${ }^{(6)}$.

The following improvements in the outpatient care at the Gastroenterology Division were proposed: organization of the consultations in order of arrival and improvement of the working conditions of employees and doctors by expanding the facilities and performing consultations by appointment. Moreover, adding standardization and computerization of scheduling appointments and the care process would greatly facilitate the work of the reception staff, generating pertinent statistics and reports for improvement in the sector.

Another problem raised by the respondents was related to the scheduling of diagnostic procedures such as upper digestive endoscopy, colonoscopy and ultrasonography and measures to facilitate the scheduling of these exams should be implemented.

There is one study stating that clients will raise their expectations with increasing quality of the services ${ }^{(28)}$. Thus, the improvement of the services provided will promote an increase in the level of demand. Increased demands, in turn, encourage service providers to strive for continuous improvement. Finally, health service assessments emerge as an important tool that can promote changes and which should not be viewed as a threat, but rather as an incentive for health services to meet minimum quality standards ${ }^{(29)}$.

\section{CONCLUSION}

It is important to emphasize the existence of laws and decrees designed to improve healthcare. It is up to managers, health professionals and users to promote respect for and compliance with these laws, and only then will we have a health system of better quality. 
RESUMO

Objetivo: Avaliar o grau de satisfação e o perfil socioeconômico de pacientes que são atendidos em Clínicas Externas de Gastrenterologia de uma instituição universitária vinculada ao Sistema Único de Saúde brasileiro. Método: Um questionário administrado por pesquisador foi aplicado durante uma entrevista estruturada em clínicas externas. Resultados: Duzentos e quarenta (240) pacientes foram incluídos no estudo (idade média de 53 anos, 55\% mulheres). Aproximadamente 30\% dos pacientes tinham ensino fundamental incompleto, $25 \%$ tinham ensino médio incompleto e $53 \%$ eram trabalhadores na ativa. Cerca de $87 \%$ dos que eram atendidos nas clínicas externas se encontravam nas classes econômicas B2, C1 e C2 com renda familiar estimada entre 275,00 e 825,00 dólares americanos por mês. Noventa e dois por cento (92\%) dos pacientes estavam satisfeitos com o atendimento recebido; os itens associados a baixo grau de satisfação foram as instalações/conforto, limpeza e tempo de espera para consulta. Nenhuma relação foi observada entre perfil socioeconômico e grau de satisfação. Conclusão: Pesquisas de satisfação são importantes para identificar oportunidades para melhorar os serviços de saúde e para que seus gerentes responsáveis, profissionais da saúde e até mesmo usuários possam promover o cumprimento às leis e decretos que visam melhorar o atendimento em saúde.

\section{DESCRITORES}

Satisfação do Paciente; Fatores Socioeconômicos; Serviços de Saúde; Sistema Único de Saúde; Brasil.

\section{RESUMEN}

Objetivo: Evaluar el grado de satisfacción y el perfil socioeconómico de pacientes atendidos en Clínicas Externas de Gastroenterología de un centro universitario vinculado al Sistema Único de Salud brasileño. Método: Un cuestionario administrado por investigador fue aplicado durante entrevista estructura en clínicas externas. Resultados: Doscientos cuarenta (240) pacientes fueron incluidos en el estudio (edad media de 53 años, el 55\% mujeres). Un 30\% de los pacientes tenían educación básica incompleta, el 25\% tenían el bachillerato/secundaria incompleto/a y el 53\% eran trabajadores activos. Cerca del $87 \%$ de los que eran atendidos en la clínicas externas se hallaban en las clases económicas B2, C1 y C2 con ingresos familiares estimados entre 275,00 y 825,00 dólares estadounidenses por mes. El noventa y dos por ciento (92\%) de los pacientes estaban satisfechos con la atención recibida; los puntos asociados con bajo grado de satisfacción fueron las instalaciones/comodidad, limpieza y tiempo de espera para consulta. Ninguna relación fue observada entre perfil socioeconómico y grado de satisfacción. Conclusión: Encuestas de satisfacción son importantes para identificar oportunidades de mejorar los servicios sanitarios y para que sus gerentes responsables, profesionales sanitarios e incluso los mismos usuarios puedan promocionar el cumplimiento a la leyes y decretos a fin de mejorar la atención sanitaria.

\section{DESCRIPTORES}

Satisfacción del Paciente; Factores Socioeconómicos; Servicios de Salud; Sistema Unico de Salud; Brasil.

\section{REFERENCES}

1. Ramos EM, Diniz IM. Breve reflexão sobre a construção da ideia de proteção social e o direito à saúde na Constituição Federal de 1988. Rev Dig Constituição Garantia Direitos [Internet]. 2016 [citado 2018 fev. 28];9(2). Disponível em: https://periodicos.ufrn.br/ constituicaoegarantiadedireitos/article/view/12254

2. Pinto EG, de Moraes Bahia AM, Santos L. O financiamento da saúde na Constituição de 1988: um estudo em busca da efetividade do direito fundamental por meio da equalização federativa do dever do seu custeio mínimo. Rev Direito Admin Constit. 2017;16(66):209-37.

3. Novaes C, Lasso S, Wagner Mainardes E. Percepções de qualidade do serviço público. Rev Pensam Contemp Admin [Internet]. 2015 [citado 2018 fev. 28];9(1):107-23. Disponível em: http://www.uff.br/pae/index.php/pca/article/view/498/372

4. Almeida HM. Programa de Qualidade do Governo Federal aplicado à saúde. Rev Admin Saúde. 2001;3(12):5-10.

5. Dalmolin BB, Backes DS, Zamberlan C, Schaurich D, Colomé JS, Gehlen MH. Significados do conceito de saúde na perspectiva de docentes da área da saúde. Esc Anna Nery [Internet]. 2011 [citado 2018 fev. 28];15(2):389-94. Disponível em: http://www.scielo.br/pdf/ ean/v15n2/v15n2a23

6. Backes DS, Koerich MS, Rodrigues ACRL, Drago LC, Klock P, Erdmann AL. O que os usuários pensam e falam do Sistema Único de Saúde? Uma análise dos significados à luz da carta dos direitos dos usuários. Ciênc Saúde Coletiva. 2009;14(3):903-10. DOI: http://dx.doi. org/10.1590/S1413-81232009000300026

7. Lin C. Patient satisfaction with nursing care as an outcome variable: dilemmas for nursing evaluation researchers. J Prof Nurs. 1996;12(4):20716.

8. Han $\mathrm{CH}$, Connolly PM, Canham D. Measuring patient satisfaction as an outcome of nursing care at a teaching hospital of southern Taiwan. J Nurs Care Qual. 2003;18(2):143-50.

9. Oliveira AML, Guirardello EB. Satisfação do paciente com os cuidados de enfermagem: comparação entre dois hospitais. Rev Esc Enferm USP [Internet]. 2006 [citado 2018 fev. 28];40(1):71-7. Disponível em: http://www.scielo.br/scielo.php?script=sci_arttext\&pid $=$ S0080-62342006000100010

10. Britto Júnior AF, Ferez Júnior N. A utilização da técnica da entrevista em trabalhos científicos. Evidência [Internet]. 2011 [citado 2018 fev. 28];7(7):237-50. Disponível em: http://www.uniaraxa.edu.br/ojs/index.php/evidencia/article/view/200/186

11. Kamakura W, Mazzon JA. Critérios de estratificação e comparação de classificadores socioeconômicos no Brasil. Rev Adm Empresa. 2016;56(1):55-70. https://dx.doi.org/10.1590/S0034-759020160106

12. Pompeu JGF, Carvalho ILD, Pereira JA, Cruz Neto RG, Prado VLG, Silva CHVD. Avaliação do nível de satisfação dos usuários atendidos na clínica integrada do curso de odontologia da Faculdade Novafapi em Teresina (PI). Odontol Clin Cient Online) [Internet]. 2012 [citado 2018 fev. 28];11(1):31-6. Disponível em: http://revodonto.bvsalud.org/pdf/occ/v11n1/a06v11n1.pdf

13. Deming WE. Qualidade: a revolução da administração. Rio de Janeiro: Marques Saraiva; 1990.

14. Silveira JAM, Hayashi L, Scarpi MJ. Identificação de necessidades e expectativas dos pacientes de uma clínica de catarata. Arq Bras Oftalmol. 2005;68(5):639-44. DOI: http://dx.doi.org/10.1590/S0004-27492005000500013 
15. Rosso JA, Silva RM. Avaliação da qualidade do atendimento em Unidades Primárias de Saúde: comparação de estruturas com e sem a presença de acadêmicos de medicina. ACM Arq Catarin Med. 2006;35(2):47-55.

16. Dorigan $\mathrm{GH}$, Guirardello EB. Satisfação do paciente em uma unidade de gastroenterologia. Acta Paul Enferm [Internet]. 2010 [citado 2018 fev. 28];23(4):500-5. Disponível em: http://www.scielo.br/scielo.php?script=sci_arttext\&pid=S0103-21002010000400009

17. Morais AS, Meilleiro MM. A qualidade da assistência de enfermagem em uma unidade de emergência: a percepção do usuário. Rev Eletr Enferm [Internet]. 2013 [citado 2018 fev. 28];15(1):112-20. Disponível em: https://www.fen.ufg.br/revista/v15/n1/pdf/v15n1a13.pdf

18. Mattos CAC, Santos DCG, Corrêa AC, Gomes SC. Serviços médico-hospitalares: fatores de satisfação dos pacientes de um hospital público de Belém-PA. Rev Pretexto. 2010;11(4):90-110.

19. Kloetzel K, Bertoni AM, Irazoqui MC, Campos VPG, dos Santos RN. Controle de qualidade em atenção primária à saúde. I A satisfação do usuário. Cad Saúde Pública. 1998;14(3):263-68. DOI: http://dx.doi.org/10.1590/S0102-311X1998000300020

20. Silva LMP, Muccioli C, Belfort Junior R. Perfil socioeconômico e satisfação dos pacientes atendidos no mutirão de catarata do Instituto da Visão - UNIFESP. Arq Bras Oftalmol. 2004;67(5):737-44. DOI: http://dx.doi.org/10.1590/S0004-27492004000500008

21. Franco SC, Sousa Campos GW. Avaliação da qualidade de atendimento ambulatorial em pediatria em um hospital universitário. Cad Saúde Pública. 1998;14(1):61-70. DOI: http://dx.doi.org/10.1590/S0102-311X1998000100014

22. Schmidt SMS, Müller FM, Santos E, Ceretta PS, Garlet V, Schmitt S. Análise da satisfação dos usuários em um hospital universitário. Saúde Debate [Internet]. 2014 [citado 2018 fev. 28];38(101):305-17. Disponível em: http://www.scielo.br/pdf/sdeb/v38n101/0103-1104sdeb-38-101-0305.pdf

23. Vaitsman J, Andrade GRB. Satisfação e responsividade: formas de medir a qualidade e a humanização da assistência à saúde. Ciênc Saúde Coletiva. 2005;10(3):599-613. DOl: http://dx.doi.org/10.1590/S1413-81232005000300017

24. Benazzi LEB, Figueiredo ACL, Bassani DG. Avaliação do usuário sobre o atendimento oftalmológico oferecido pelo SUS em um centro urbano no sul do Brasil. Ciênc Saúde Coletiva. 2010;15(3):861-8. DOI: http://dx.doi.org/10.1590/S1413-81232010000300029

25. Andrade LM, Martins EC, Caetano JA, Soares E, Beserra EP. Atendimento humanizado nos serviços de emergência hospitalar na percepção do acompanhante. Rev Eletr Enf [Internet]. 2009 [citado 2018 fev. 22];11(1):151-7. Disponível em: http://www.fen.ufg.br/revista/v11/n1/ v11n1a19.htm

26. Gouveia CG, Souza WV, Luna CF, Souza Junior PRB, Szwarcwald CL. Satisfação dos usuários do sistema de saúde brasileiro: fatores associados e diferenças regionais. Rev Bras Epidemiol [Internet] 2009 [citado 2018 fev. 28];12(3):281-96. Disponível em: https://www. scielosp.org/pdf/rbepid/v12n3/01.pdf

27. Paiva SMA, Gomes ELR. Assistência hospitalar: avaliação da satisfação dos usuários durante seu período de internação. Rev Latino Am Enfermagem [Internet]. 2007 [citado 2018 fev. 28];15(5). Disponível em: http://www.scielo.br/pdf/rlae/v15n5/pt_v15n5a13.pdf

28. Parente J. Varejo no Brasil: gestão e estratégia. São Paulo: Atlas; 2000.

29. Righi AW, Schmidt AZ, Venturini JC. Qualidade em serviços públicos de saúde: uma avaliação da estratégia saúde da família. Rev Produção Online [Internet]. 2010 [citado 2018 fev. 28];10(3):649-69. Disponível em: https://producaoonline.org.br/rpo/article/viewFile/405/721 